
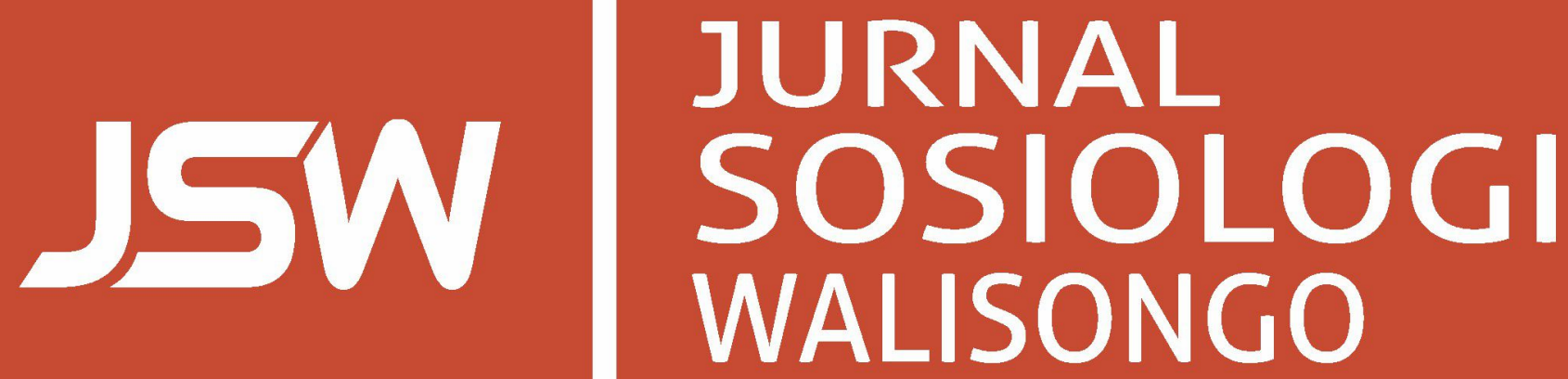

Studi Etnoekologi tentang Nelayan dan Jaring Cantrang

di Kabupaten Rembang

Hesti Rofika Sari, Nugroho Trisnu Brata

Perlawanan Visual Perempuan dalam Poster

Misbah Zulfa Elizabeth

Kearifan Budaya Lokal sebagai Benteng Munculnya Konflik Agama Muhammad Alfan Sidik

Ulama Pasca Sunan Gunung Jati: Jaringan Intelektual Islam Cirebon Abad ke-16 sampai dengan Abad ke-18

Didin Nurul Rosidin

Membangun Harmoni Sosial: Kajian Sosiologi Agama tentang Kearifan Lokal sebagai Modal Dasar Harmoni Sosial David Samiyono

Analisis Komparatif atas Hasil Tracer Study Program Studi Hubungan Internasional dan Administrasi Negara Muhyar Fanani, Akhriyadi Sofian, Kaisar Atmaja, Endang Supriadi

Melihat Indonesia dari Jendela Papua: Kebinekaan dalam Rajutan Budaya Melanesia Akhmad Kadir 

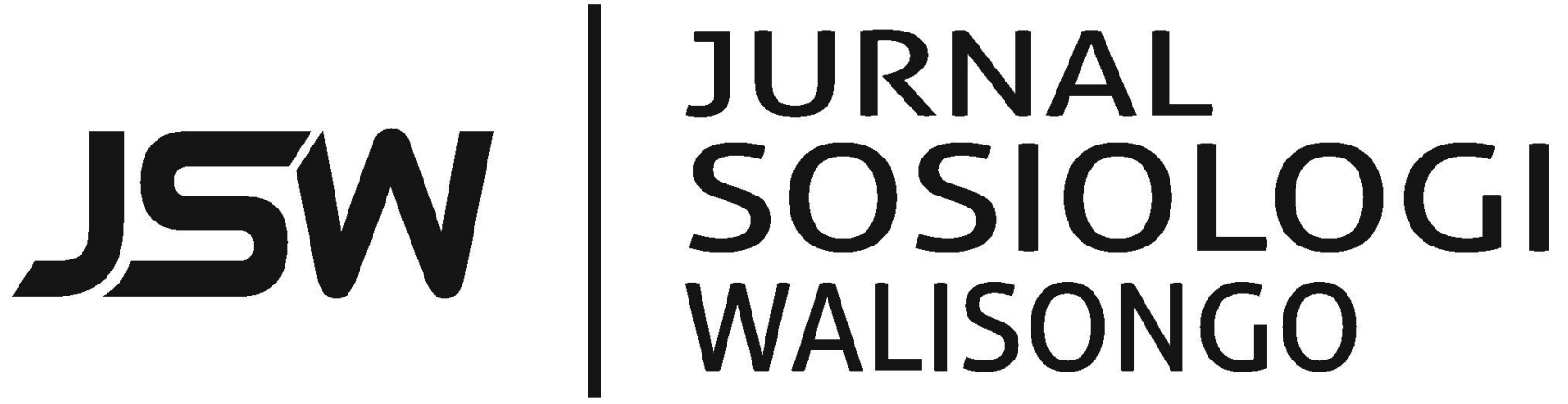

JSW: Jurnal Sosiologi Walisongo - ISSN 2503-3166 (print) ISSN 2503-3182 (online) is a critical, reflective, and transformative academic media that is published by Laboratorium Sosiologi, Fakultas IImu Sosial dan IImu Politik, Universitas Islam Negeri Walisongo Semarang, in the effort for developing the discipline of Sociology having the perspective of unity of sciences. Article is based on research in all division of sociology like sociology of religion, sociology of politic, sociology of law, sociology of development, urban/rural sociology, democracy, social ethic, anthropology, community development, social philosophy, gender, and social welfare.

\section{Editor in Chief}

Misbah Zulfa Elizabeth, Universitas Islam Negeri Walisongo, Semarang

\section{Expert Editor}

Abu Rokhmad, Universitas Islam Negeri Walisongo, Semarang

Muhyar Fanani, Universitas Islam Negeri Walisongo, Semarang

Thohir Yuli Kusmanto, Universitas Islam Negeri Walisongo, Semarang

\section{Editor}

Kaisar Atmaja, Universitas Islam Negeri Walisongo, Semarang

Akhriyadi Sofian, Universitas Islam Negeri Walisongo, Semarang

Nur Hasyim, Universitas Islam Negeri Walisongo, Semarang

\section{Layout Editor}

Helmi Suyanto, Universitas Islam Negeri Walisongo, Semarang

Ulul Azmi, Universitas Islam Negeri Walisongo, Semarang

\section{Publisher}

LABORATORIUM SOSIOLOGI

Fakultas IImu Sosial dan IImu Politik

Universitas Islam Negeri Walisongo

Semarang - Indonesia

\section{Address}

Gedung A - Fakultas IImu Sosial dan IImu Politik (FISIP)

Universitas Islam Negeri Walisongo, Semarang - Indonesia

Jl. Prof. Dr. HAMKA, Km. 2 Tambakaji Ngaliyan Semarang 50185

Phone +62.24 - 76435986

e-mail:jurnal.sosiologi@walisongo.ac.id 


\section{Table of Contents}

Studi Etnoekologi tentang Nelayan dan Jaring Cantrang di Kabupaten Rembang

Hesti Rofika Sari, Nugroho Trisnu Brata (Universitas Negeri

Semarang)

$135-146$

Perlawanan Visual Perempuan dalam Poster

Misbah Zulfa Elizabeth (Universitas Islam Negeri Walisongo,

Semarang)

$147-160$

Kearifan Budaya Lokal sebagai Benteng Munculnya

Konflik Agama

Muhammad Alfan Sidik (STAI Natuna)

$161-176$

Ulama Pasca Sunan Gunung Jati: Jaringan Intelektual Islam

Cirebon Abad ke-16 sampai dengan Abad ke-18

Didin Nurul Rosidin (Institut Agama Islam Negeri Syekh Nurjati,

Cirebon)

$177-194$

Membangun Harmoni Sosial: Kajian Sosiologi Agama tentang

Kearifan Lokal sebagai Modal Dasar Harmoni Sosial

David Samiyono (UKSW, Salatiga)

$195-206$

Analisis Komparatif atas Hasil Tracer Study Program Studi

Hubungan Internasional dan Administrasi Negara

Muhyar Fanani, Akhriyadi Sofian, Kaisar Atmaja, Endang Supriadi

(Universitas Islam Negeri Walisongo, Semarang)

$207-224$

Melihat Indonesia dari Jendela Papua: Kebinekaan dalam

Rajutan Budaya Melanesia

Akhmad Kadir (Universitas Cendrawasih, Jayapura)

$225-246$

Author Guidelines

JSW: Jurnal Sosiologi Walisongo - Vol 1, No 2 (2017) 



\title{
Studi Etnoekologi tentang Nelayan dan Jaring Cantrang di Kabupaten Rembang
}

\author{
Hesti Rofika Sari, ${ }^{1}$ Nugroho Trisnu Brata ${ }^{2}$ \\ Universitas Negeri Semarang \\ (e-mail: 1hestialdila95@gmail.com; 2trisnu_ntb2015@unnes.ac.id)
}

\begin{abstract}
The article discuss about ecology among fisherman community who use cantrang nets in Tasik Agung village, Rembang Regency. The purpose in this research is to know the local wisdom in Utilizing cantrang nets and the impact of banning the use of cantrang nets. This research uses qualitative method. The result of this research in analized by using determinisme theory from Julian Steawerd and concept of adaptation and environment form Kaplan. The result of this study indicate that the cultural system and local knowledge in the community Tasik Agung village is a prcess of understanding the environtment. And the prohibition of the use of nets cantrang overall impact not only the fisherman who feel but the wider community also impact.
\end{abstract}

Artikel ini membahas tentang ekologi di kalangan masyarakat nelayan yang menggunakan jaring cantrang di Desa Tasik Agung, Kabupaten Rembang. Tujuan dalam penelitian ini adalah untuk mengetahui kearifan lokal dalam memanfaatkan jaring cantrang dan dampak pelarangan penggunaan jaring cantrang. Penelitian ini menggunakan metode kualitatif. Hasil penelitian ini dianalisa dengan menggunakan teori determinisme dari Julian Steawerd dan konsep adaptasi dan lingkungan dari Kaplan. Hasil penelitian ini menunjukkan bahwa sistem budaya dan kearifan lokal masyarakat Desa Tasik Agung merupakan prasangka untuk memahami lingkungan. Pelarangan penggunaan jaring cantrang secara keseluruhan berdampak tidak hanya nelayan yang merasakan tetapi masyarakat luas juga berdampak..

Keywords: cantrang; impact of the ban; ecology; local knowledge

\section{Pendahuluan}

Kabupaten Rembang memiliki posisi geografis yang terbagi mejadi dua yakni, bagian selatan berbatasan dengan Gunung Kendeng dan bagian utara berbatasan langsung dengan Laut Jawa. Masyarakat 
yang berdomisili di bagian utara umumnya bermata pencaharian sebagai nelayan. Masyarakat nelayan adalah masyarakat yang hidup, tumbuh, dan berkembang di kawasan pesisir, yakni suatu kawasan transisi antara daratan dan laut. Selain bermata pencaharian sebagai nelayan, ada juga yang menjadi petani tambak, atau pembudidaya perairan. Aktivitas seharihari seorang nelayan sangat berbeda dengan seseorang yang menjadi petani. Hal tersebut yang membuat konstruksi sosial yang terdapat pada masyarakat pesisir berbeda dengan masyarakat non pesisir. Sehingga, kebudayaan nelayan berpengaruh besar terhadap terbentuknya identitas kebudayaan masyarakat pesisir secara keseluruhan (Ginkel 2007).

Kebudayaan yang terbentuk dalam suatu wilayah salah satunya dipengaruhi oleh teknologi yang digunakan. Dalam hal teknologi, nelayan Desa Tasik Agung mempunyai teknologi alat tangkap ikan yang telah dimodifikasi. Awalnya nelayan menganggap bahwa dengan teknologi jaring trawl nelayan mendapatkan hasil tangkap yang lebih. Sayangnya, sejak rezim Soeharto jaring trawl dilarang. Padahal jaring ini dianggap alat penangkapan ikan yang efektif dengan hasil maksimal. Karena dilarang, maka nelayan Desa Tasik Agung memodifikasi trawl menjadi jaring cantrang. Perberbedaan jaring trawl dengan jaring cantrang terletak pada papan pembuka, dimana ciri jaring trawl adalah papan pembuka yang disebut dengan istilah pukat harimau. Pada jaring cantrang papan pembuka tersebut dihilangkan karena dilarang oleh pemerintah. Akan tetapi bentuk dan penampang dari jaring cantrang sama persis dengan jaring trawl. Kemudian nelayan memanfaatkan jaring cantrang untuk alat tangkap ikan yang efektif dan tidak dilarang.

Alat tangkap yang digunakan nelayan memengaruhi tingkat kesejahteraan nelayan (Yapanani et al. 2013). Beberapa riset menunjukkan kesimpulan seperti di atas (Satria 2015; Sukmawati 2008; Yapanani et al. 2013; Kalita et al. 2015; Zamron 2015; Ermawati dan Zuliyati 2015; Aji et al. 2013). Alat penangkap ikan yang digunakan oleh nelayan Desa Tasik Agung telah menggunakan teknologi modern. Salah satunya yaitu jaring cantrang. Sistem kerja dari jaring cantrang tersebut ditarik dengan menggunakan mesin gardan. Nelayan menyebut kapal yang mereka gunakan untuk pergi melaut sesuai dengan alat tangkap yang digunakan pada sebuah kapal. Sebenarnya masih banyak tipe nelayan berdasarkan alat tangkapnya yang ada di Rembang missalnya saja nelayan koersin, gardan, freezer, bobo, cantrang dan nelayan tradisional. Tetapi yang menjadi fokus kajian di sini adalah pemanfaatan jaring cantrang. Pemanfaatan jaring cantrang oleh nelayan kemudian 
dipandang pemerintah sebagai perbuatan ekspoitatif dan dampaknya dapat merusak ekosistem laut sehingga jaring ini kemudian dilarang. Pelarangan penggunaan alat tangkap cantrang melalui Peraturan Menteri Kelautan dan Perikanan Republik Indonesia No. 02 Tahun 2015, serta Peraturan Menteri Kelautan dan Perikanan Republik Indonesia No. 71 tahun 2016 (Kompas, 19 Januari 2018: 1). Hal ini membuat resah nelayan, termasuk nelayan di Desa Tasik Agung.

Di Desa Tasik Agung yang penduduknya mayoritas nelayan ditemukan adanya struktur organisasi kerja nelayan cantrang yaitu; juragan, juru mudi, juru payang, juru teknis, juru masak, dan anak buah kapal (ABK), termasuk juga para pekerja yang bergelut dalam perikanan tangkap. Mereka menggantungkan hidupnya dari hasil melaut. Masyarakat Desa Tasik Agung mempunyai tradisi yang diadakan setiap tahun yaitu sedekah laut. Ritual tersebut menghabiskan banyak biaya yang diperoleh dari iuran kelompok-kelompok nelayan.

Menurut masyarakat, prosesi ritual sedekah laut ditujukan untuk penghormatan kepada dewa laut. Mereka beranggapan bahwa di lautan luas terdapat "dewa” yang bertugas menjaga laut. Dalam pelaksanaan ritual sedekah laut, nelayan mengungkapkan harapan yaitu bisa melaut dengan selamat dan membawa pulang hasil tangkapan yang banyak. Ritual sedekah laut dilakukan selama satu minggu diawali dengan larung sesajen (menghanyutkan sesaji) ke laut dan dilanjutkan dengan berbagai pertunjukan hiburan. Acara hiburan yang selalu ada ketika acara sedekah laut adalah nanggap dangdut (mengadakan konser dangdut). Para nelayan mempunyai kebiasaan nyawer biduan (memberi uang pada penyanyi dangdut). Nyawer sejatinya adalah "pertunjukan di dalam pertunjukan". Orang yang nyawer dalam pertunjukan dangdut sedang membuat pertunjukan juga, siapa yang nyawer dengan uang paling banyak maka orang tersebut dianggap (merasa) prestise-nya paling tinggi dalam masyarakat. Ritual sedekah laut dan pertunjukan dangdut adalah bentuk ekspresi pemaknaan masyarakat nelayaan terhadap ekologi mereka.

Ekologi laut mempengaruhi munculnya kebudayaan yang ada di daerah tersebut. Perilaku manusia dipengaruhi oleh lingkungan ekologinya dalam rangka mereka memanfaatkan kawasan pesisir tersebut. Artikel ini berusaha mengkaji ekologi masyarakat nelayan cantrang Desa Tasik Agung Kabupaten Rembang yang berhubungan dengan lingkungan dan teknologi pemanfaatan serta teknologi produksi.

Tujuan penelitian ini untuk memahami pengetahuan ekologi di kalangan nelayan pengguna cantrang dengan perspektif etnoekologi yang telah berkembang dalam antropologi. 
Penelitian ini menggunakan metode kualitatif dengan fokus kajian pada pemaknaan ekologi di kalangan nelayan cantrang di Desa Tasik Agung Kabupaten Rembang Provinsi Jawa Tengah. Perspektif etnoekologi meliputi pengetahuan lokal nelayan tentang jaring cantrang dan juga dampak pelarangan pengoperasian jaring cantrang. Lokasi penelitian ini adalah Desa Tasik Agung Kabupaten Rembang. Image nelayan yang marginal tidak berlaku di desa ini. Subjek penelitian adalah nelayan cantrang Desa Tasik Agung. Informan utama dalam penelitian ini yaitu ketua nelayan cantrang dan pemilik kapal. Informan pendukung dalam penelitian ini yaitu kepala desa dan keluarga. Teknik pengumpulan data dengan observasi, wawancara dan studi literatur. Metode analisis data berpijak pada perspektif etnoekologi yang bersumber dari ilmu antropologi.

Menurut Brata (2008: 112), bahwa Ahimsa-Putra (1994: 6) mengatakan jika kita perhatikan berbagai studi antropologi ekologi di tahun 1960-an yang dibangkitkan oleh ekologi budaya dari Julian Steward, maka dapat diklasifikasikan berbagai studi ini paling tidak dalam 4 aliran, yaitu; 1) Pendekatan etnoekologi; aliran ini dicetuskan oleh ahli antropologi dengan latar belakang linguistik yang kuat. Tujuan dan metode dari pendekatan ini banyak berasal dari etnosains, dan pertama kali dikenalkan oleh Conklin (1954) serta di dukung oleh Frake. 2) Pendekatan ekologi silang-budaya; pendekatan ini tampak dalam studi yang dilakukan oleh Netting (1968, 1969) dan Goldschmid et al. (1965). Netting melakukan penelitian di kalangan orang Kofyar di Nigeria tahun 1960-1962 dan dipengaruhi oleh ekologi budaya dari Steward. 3) Pendekatan ekosistemik kultural; aliran ini diwakili oleh buku Geertz yang berjudul Agricultural Involution (1963). Aliran ketiga dalam antropologi ekologi ini adalah pendekatan ekosistem. Kerangka teori/paradigma ekosistem ini mendapatkan modelnya dari ilmu biologi dan ekologi umum. Dan 4) Pendekatan ekosistemik material; aliran ini terdapat dalam berbagai studi yang dilakukan oleh para ahli antropologi yaitu Andrew Vayda (1961, 1967), Roy Rappaport (1967, 1968, 1971), Marvin Harris (1966), dan Antony Leeds (1965). Aliran ini adalah aliran antropologi neo-fungsional (neo-fungtional ecology). Dua dari 4 aliran di atas, yaitu etnoekologi dan ekosistemik meterial (ekologi neo-fungsional dari Andrew Vayda dkk), sampai saat sekarang masih tetap populer di kalangan peminat ilmu antropologi ekologi (Ahimsa-Putra 1994: 6).

\section{Gambaran Geografis Desa Tasik Agung}

Desa Tasik Agung adalah salah satu desa di Kabupaten Rembang yang letaknya berbatasan langsung dengan Pantai Utara Jawa. Desa Tasik Agung terdiri dari empat pedukuhan yaitu Rembangan, 
Kramatan, Pabean, dan Dukuh Gandilangu. Desa Tasik Agung sendiri terletak di wilayah ibukota Kabupaten Rembang, selain itu berbatasan langsung dengan wisata Bahari Pantai Kartini. Wilayah yang strategis tersebut menjadikan Desa Tasik Agung lebih maju dibandingkan dengan desa-desa yang lain di wilayah Rembang. Mulai dari letaknya yang dekat dengan Kantor Pemkab Rembang, hingga penataan wilayah pelabuhan yang diorientasikan sebagai tempat wisata bahari menjadi daya tarik tersendiri untuk berwisata ke Desa Tasik Agung. Hal tersebut membuat pendapatan daerah semakin meningkat. Adapun batas-batas Desa Tasik Agung adalah:

$$
\begin{array}{ll}
\text { Sebelah Utara } & \text { : Laut Jawa } \\
\text { Sebelah Timur } & \begin{array}{l}
\text { Gedung DPRD Kabu- } \\
\text { paten Rembang }
\end{array} \\
\text { Sebelah Selatan } & \text { Jalan Raya Semarang } \\
& \text { - Surabaya } \\
\text { Sebelah Barat } & \text { : Sungai Karang } \\
& \text { Geneng }
\end{array}
$$

Penduduk Desa Tasik Agung mayoritas bermata pencaharian sebagai nelayan, selain itu ada juga yang mengolah hasil tangkap. Penulis melihat berbagai aktivitas yang dilakukan oleh masyarakat dalam kesehariannya, mulai dari kesibukan di pelabuhan pada siang hari, banyaknya pabrik pengasianan ikan, pengolahan ikan, pabrik es batu, bengkel mesin kapal dan juga bengkel jaring, serta banyak warungwarung makan di sepanjang jalan pe- labuhan. Kesibukan masyarakat tersebut sebagai bentuk dari pemanfaatan Sumber Daya Alam yang telah tersedia. Kepandaian ataupun pengetahuan masyarakat dalam mengolah Sumber Daya Alam laut sebagai bentuk adaptasi nelayan terhadap lingkungan tempat tinggal mereka (Satria 2015).

Lingkungan sosial di Desa Tasik Agung, merupakan lingkungan yang padat penduduk. Selain bangunan rumah penduduk, di Rembang pada umumnya juga banyak terdapat warung kopi, café, tempat billyard, dan hotel. Tempat-tempat tersebut dikunjungi oleh nelayan sebagai tempat hiburan ketika sedang tidak bekerja melaut. Embel-embel madon (main perempuan), minom (meminum minuman beralkohol sampai mabuk), lan main (dan berjudi) dari jaman dulu memang telah disandang oleh para nelayan, dan sampai sekarangpun ketiga hal tersebut masih melekat pada nelayan. Permasalahanpermasalahan pada rumah tangga nelayan bukan lagi faktor ekonomi melainkan ketidakharmonisan dalam rumah tangga. Penulis menyaksikan sendiri, ketika tinggal di lokasi penelitian banyak bapak yang sering keluar malam dan pulangnya menjelang pagi. Hal tersebut juga terjadi pada informan kunci yaitu mbah Pingi, ia mempunyai dua istri, dan juragan kapal kecik atau sering disingkat "kapal KCK" yang juga mempunyai dua istri. Istri mudanya adalah seorang biduan dangdut, dan tidak 
lama umur pernikahan itu kemudian biduan tersebut diceraikan karena ia sadar kalau biduan tersebut hanya tertarik pada hartanya.

\section{Hubungan Lingkungan dengan Teknologi Pemanfaatan}

Dalam rangka menjaga ekosistem laut mereka (nelayan) memodifikasi teknologi penangkap ikan jaring trawl yaitu memodifikasi alat tersebut dengan meniadakan papan pembuka atau yang disebut pukat harimau. Pukat harimau pada jaring trawl dapat merusak ekosistem bawah laut karena sistem kerja yang tidak ramah lingkungan. Papan pembuka pada jaring trawl tersebut akan terus terbuka sepanjang kapal berjalan, sehingga jaring trawl dilarang oleh pemerintah untuk dioperasikan di wilayah perairan Indonesia.

Selain menggunakan teknologi yang ramah lingkungan untuk menangkap ikan, masyarakat Desa Tasik Agung masih melaksanakan ritual rutin setiap tahunnya yaitu sedekah laut. Mereka percaya bahwa ritual sedekah laut harus selalu dilaksanakan dengan harapan nelayan mendapatkan perlindungan selama melaut dan mendapatkan hasil tangkap yang banyak. Penge-tahuan lokal masih tetap dijaga oleh masyarakat nelayan Desa Tasik Agung khususnya mereka nelayan yang dianggap sebagai sesepuh di desa. Walaupun keberadaaaan kapal-kapal sekarang telah dilengkapi teknologi-teknologi modern namun tetap saja nelayan masih mempercayai keberadaan "ilmu titen". Nelayan
Desa Tasik Agung mempunyai aturan musim dalam menangkap ikan yang disebut pranata mangsa. Pranata mangsa merupakan hitungan bulan atau musim tangkap, dalam pranata mangsa nelayan mengaitkan musim tangkap dengan tandatanda yang terdapat pada alam. Tandatanda yang ditunjukkan alam adalah kemunculan bintang, arah datangnya angin, dan kenampakan ombak maupun arus di laut. "Ilmu titen" tersebut digunakan nelayan Desa Tasik Agung untuk memprediksi bagaimana pelayaran selama di laut dan hasil tangkapan dalam sekali melaut.

\section{Sistem Pengetahuan Lokal Nelayan dengan Cantrang}

Pengetahuan nelayan berkembang berdasarkan pengalaman terdahulu, demikian pula dengan alat tangkap yang dianggap produktif dan efisien untuk mendapatkan hasil dengan nilai ekonomis yang tinggi dan tidak tergantung pada musim adalah alat tangkap cantrang. Armada yang digunakan yaitu kapal kayu berbagai ukuran (setelah diverifikasi antara 20 - 80 GT) dan penarikan alat tangkap dengan mesin. Hasil dari tangkapan sama dengan untuk umpan nelayan bobo dan nelayan pancing. Kalau zaman dulu nelayan yang menggunakan perahu dan alat tangkap ikan tradisional seperti jaring klitik maupun pancing tidak membutuhkan banyak tenaga kerja, biasanya hanya berkisar 3-4 orang. Tenaga kerja itupun biasanya diambil dari keluarga sendiri yang terdiri dari kepala 
keluarga, anak laki-laki, dan anak menantu laki-laki. Perahu-perahu tersebut saat melaut tidak melebihi jarak 12 mil dari pantai. Biasanya nelayan berangkat pukul 03.00 WIB dan kembali pukul 15.00 WIB. Hasil tangkapan biasanya, diserahkan kepada istri (perempuan yang dirumah) untuk dijual ke tetangga atau ider, kalau tidak habis biasanya digunakan untuk lauk sendiri. Uang hasil penjualan akan digunakan untuk memenuhi kebutuhan sehari-hari dari kebutuhan biologis hingga kebutuhan sosial seperti buoh (memberikan sumbangan kepada orang yang punya hajatan).

Dinamika nelayan Tasik Agung setelah beralihnya alat tangkap tradisional ke jaring cantrang membuat struktur kerja pun bergeser atau mengalami strukturasi. Setelah menggunakan jaring cantrang dengan armada kapal yang berukuran 20 hingga 80 GT, membutuhkan banyak tenaga kerja untuk mengoperasikan kapal. Kapal-kapal cantrang mempunyai struktur kerja yang kompleks, hal ini ditunjukkan spesifikasi pembagian kerja setiap crew dalam kapal. Setiap ABK kapal cantrang mempunyai keahlian masing-masing sehingga sangat membantu dalam sekali pelayaran. Karena setiap ABK mempunyai tanggung jawab pada bidangnya sendiri. Dalam istilah lokal ABK kapal cantrang terdiri dari juru mudi, juru mesin, juru payang, juru jegong, juru masak, dan ABK biasa. Penempatan setiap ABK didasarkan atas pengetahuan yang mereka miliki.

Sekali melaut kapal cantrang membutuhkan 15-17 orang anak buah kapal (ABK). Mereka menempati beberapa bagian yang dibutuhkan dalam satu kesatuan yaitu melaut. Susunan dari bagian yang paling atas adalah nahkoda yang bertugas sebagai pimpinan di kapal, nahkoda memegang peranan sangat penting. Dari memimpin kapal hingga mengetahui letak keberadaan ikan. Dibawah nahkoda ada juru mudi yang terdiri satu orang yaitu yang menggerakkan kapal atau sebagai pengemudi kapal, di bawahnya lagi ada juru mesin atau yang sering disebut dengan motoris ia bertugas untuk menjaga mesin kapal, setelah itu ada juru payang bertugas mengurus jaring yang digunakan untuk menangkap ikan di laut, selanjutnya ada juru jegong yang bertugas mengurus ikan hasil tangkapan, dan terakhir ada juru masak yang bertugas memasak setiap hari untuk makan seluruh crew dalam kapal.

\section{Sistem Bagi Hasil}

Ada dua tipe aturan bagi hasil antara juragan-ABK, yaitu aturan biasa dan aturan darurat ketika hanya sedikit hasil tangkapan yang diperoleh. Aturan darurat telah sedikit disinggung di muka, yaitu model serang rata. Sedang aturan biasa masih dibedakan menjadi sedikitnya dua, 
Tabel 1. Jenis-jenis Bagen (Bagi Hasil)

\begin{tabular}{|l|c|c|}
\hline \multicolumn{1}{|c|}{ Penerima } & Istilah Lokal & Arti \\
\hline Juragan & Bagen prau & Hasil kapal \\
& Bagen jaring & Hasil jaring \\
& Bagen awak & Upah kerja \\
\hline ABK & Bagen awak & Upah Kerja \\
\hline Juru Mudi & Bagen awak & Upah jabatan \\
& Bagen pegawe & Bonus \\
& Pek/ bonus & Upah kerja \\
& Bagen awak & Upah jabatan \\
\hline Juru Mudi dan Jabatan lain & Bagen pegawe & Upah kerja \\
\hline ABK biasa & Bagen awak & \\
\hline
\end{tabular}

yaitu model telung bagen (tiga bagian) dan papat enem (empat enam). Model telung bagen yaitu pembagian hasil dengan juragan mendapat tiga porsi bagen; bagen awak, bagen prau, dan bagen jaring; dan setiap $\mathrm{ABK}$ masing-masing mendapat satu bagen. Cara ini biasanya diterapkan pada perahu-perahu yang memerlukan sedikit ABK.

Mengenai kapal, maka kapal bagi nelayan Desa Tasik Agung memiliki dua fungsi teknis yaitu sebagai alat angkut dari pangkalan kerja ke tempat-tempat penurunan jaring, dan sebagai landas pijak para nelayan dalam menurunkan jaring. Dengan dua fungsi ini, kapal memungkinkan para nelayan bergerak mengarungi laut yang luas dan menurunkan jaring nyaris di sembarang titik. Kapal merupakan salah satu indikator meningkatnya intensifikasi upaya manusia dalam mengeksploitasi sumber daya hewan air. Dengan kapal, nelayan bukan hanya menunggu ikan menghampiri alat tangkap mereka, namun secara aktif mengejar kemanapun ikan berada.

\section{Bekal Melaut dan Tempat Menjual Hasil}

Pelayaran tidak dapat dilakukan tanpa perbekalan, baik bekal untuk mesin kapal maupun ABKnya. Bekal untuk perahu adalah minyak solar, minyak pelumas cadangan, es batu untuk mengawetkan hasil tangkapan, dan bahan makanan mentah untuk kira-kira cukup 25 hari. Biasanya yang membelanjakan perbekalan laut adalah istri dari juragan kapal. Pembiayaan untuk perbekalan kapal melaut, merupakan dari pinjaman pemilik kapal terlebih dahulu. Untuk membeli bahanbahan makanan selama di kapal, biasanya diperoleh dari pasar dengan alasan masih fresh. Total setiap kali berbelanja bahan kebutuhan untuk makan sekitar dua puluh lima juta hingga tiga puluh juta rupiah, itu untuk kapal yang berukuran 30 GT. Belum lagi biaya untuk membeli es batu, solar, dan minyak pelumas mesin kapal. Apabila 
ditotal semuanya mencapai delapan puluh juta. Untuk membayar biaya perbekalan biasanya dipinjami dulu oleh pemilik kapal. Kemudian pinjaman itu dikembalikan dengan uang hasil dari penjualan tangkapan ikan.

Tempat pelelangan ikan di Desa Tasik Agung berada di dekat pantai, dan di dekat TPI tersebut dua dermaga untuk menambatkan kapal yang akan bongkar ikan. Tempat pelelangan ikan di Desa Tasik Agung di kelola langsung oleh Dinas Perikanan Kabupaten Rembang. Tempat Pelelangan Ikan di Tasik Agung merupakan tempat pelabuhan terbesar di Jawa Tengah. Kapal-kapal nelayan dari Batang, Juwana, dan Sarang juga melakukan bongkar ikan di pelabuhan Tasik Agung. Fasilitas yang terdapat di TPI Tasik Agung ini adalah dua tempat pelelangan ikan yaitu kapal cantrang dan kapal pursen (purse seine), dua dermaga, satu buah mushalla, halaman parkir yang luas, SPBU (solar), pabrik es batu, dan warung makan maupun warung yang menjual kebutuhan nelayan.

\section{Dampak Pelarangan Jaring Cantrang}

Pemanfaatan jaring cantrang oleh nelayan dianggap pemerintah berdampak negatif bagi keberlangsungan hidup biota laut. Sistem kerja jaring cantrang yang tidak ramah lingkungan menyebabkan ekosistem laut terganggu. Pendapat ter- sebut diperkuat dengan penelitian yang dilakukan Ermawati dan Zuliyati di daerah Juwana Kabupaten Pati. Dalam penelitiannya Ermawati dan Zuliyati mengatakan, "Dalam dua dekade terakhir, alat penangkapan ikan jenis trawl telah berkembang pesat dalam bentuk dan nama yang beragam, dan semuanya mengacu pada sifat penangkapannya yang tidak ramah lingkungan. Penggunaan jaring trawl dengan mengeruk dasar perairan merusak habitat serta penggunaan mata jaring yang kecil juga menyebabkan tertangkapnya berbagai jenis biota yang masih anakan atau belum matang" (Nanik Ermawati dan Zuliyati 2012).

Sistem tangkap yang mengesampingkan kelestarian lingkungan laut sangat membahayakan ekosistem laut. Demi kelestarian laut kemudian pemerintah mengeluarkan kebijakan pelarangan penggunaan jaring cantrang untuk menangkap ikan di perairan NKRI. Hal ini menimbulkan sebuah guncangan hebat bagi nelayan khususnya nelayan cantrang.

Pelarangan penggunaan alat tangkap cantrang melalui peraturan Menteri Kelautan dan Perikanan Republik No. 02 Tahun 2015 menimbulkan banyak protes dari masyarakat khususnya nelayan. Seperti yang dimuat pada Radar Pekalongan (20 Januari 2015) ratusan nelayan Kabupaten Batang pada hari Senin 19 Januari 2015 menggelar aksi unjuk rasa di Tempat Pelelangan Ikan (TPI) Batang 
dan Kantor Unit Penyelenggara Pelabuhan Kelas III Batang untuk menolak munculnya Peraturan Menteri (Permen) Kelautan dan Perikanan No. 02 Tahun 2015 yang dinilai memberatkan nelayan karena setidaknya sekitar 99 persen nelayan Batang menggunakan kapal cantrang, sehingga pelarangan penggunaan alat tangkap cantrang dapat mengakibatkan pengangguran besar-besaran. Permen tersebut juga membuat nelayan Batang kehilangan mata pencaharian. Dampak dari Permen tersebut tidak hanya pada nelayan, tapi juga para kerja yang bergelut dengan perikanan tangkap.

Cantrang telah menjadi bagian dari kehidupan masyarakat nelayan, maka dari itu nelayan tidak merespon dengan baik pelarangan penggunaan jaring cantrang. Bentuk-bentuk penolakan yang dilakukan oleh nelayan antara lain; mogok melaut, melakukan aksi demo, memblokade jalan, dan masih banyak nelayan yang melanggar peraturan dengan tetap melaut menggunakan jaring cantrang. Nelayan tidak mudah untuk berpindah alat tangkap, karena disadari bahwa nelayan cantrang khususnya telah menjadi satu kesatuan dengan sistem sosial yang terdapat di masyarakat. Di sini terlihat adanya fenomena illegal fishing, yaitu aktivitas bekerja menangkap ikan dengan jaring cantrang tetap berlangsung walau melanggar aturan hukum yaitu Peraturan
Menteri Kelautan. Illegal fishing tetap berlangsung karena aparat pemerintah tidak tegas memberi sangsi hukum bagi pelaku pelanggar hukum.

Aksi demo penolakan nelayan cantrang berlangsung selama dua tahun yaitu dari tahun 2015 hingga di tahun 2016. Nelayan seluruh Indonesia menyuarakan bahwa pihak nelayan sangat di rugikan dengan adanya kebijakan tersebut. Tetapi yang paling gencar melakukan aksi unjuk rasa adalah nelayan yang berada di Jawa. Nelayan yang ada di Jawa Tengah pernah bersatu yaitu nelayan Rembang hingga nelayan Tegal pergi ke Jakarta menuntut untuk mencabut kebijakan tersebut. Selama dua tahun tersebut nelayan cantrang melakukan aksi demo misalnya dengan turun di jalan dan membloikade jalan, mogok melaut, dan aksi lainnya. Nelayan yang melakukan demo dengan mogok melaut, dampaknya sangat luar biasa. Baik pemerintah, nelayan, pengusaha, dan rumah tangga mereka ikut merasakan.

Banyak orang mengeluh akibat pelarangan penggunaan jaring cantrang, hal itu sangat dirasakan dampaknya oleh masyarakat Desa Tasik Agung Kabupaten Rembang. Hal ini dikarenakan pola kehidupan masyarakat nelayan semuanya mempengaruhi atau membentuk lingkaran saling terhubung. Misalnya saja yang dirasakan pabrik es batu, pabrik es batu 
yang biasanya beroperasi karena permintaan kapal sekarang menjadi berhenti beroperasi karena tidak ada kapal melaut. Pabrik es batu yang berada di dekat pelabuhan kebanyakan adalah milik orang Tasik Agung. Masyarakat Desa Tasik Agung yang letak geografisnya dekat dengan pantai membuat mata pencaharian mereka semuanya mengandalkan hasil alam dari laut. Masyarakat bekerja menjadi pembuat tali selambar untuk jaring cantrang, menjadi bengkel mesin kapal, bengkel jaring, dan menjual kebutuhan nelayan serta kebutuhan kapal untuk melaut.

\section{Kesimpulan}

Berdasarkan uraian di muka maka pada bagian ini dapat ditarik adanya benang merah berupa simpulan, yaitu; Masyarakat memaknai lingkungan mereka yang berupa laut sebagai sumber daya alam yang dapat memberi manfaat kehidupan bagi masyarakat. Masyarakat menggunakan sistem pengetahuan lokal dan teknologi untuk memanfaatkan atau mengeksploitasi kekayaan alam laut. Pemanfaatan teknologi jaring cantrang oleh nelayan di Desa Tasik Agung Kabupaten Rembang adalah cara untuk mencukupi kebutuhan hidup masyarakat nelayan tanpa mengesampingkan kelestarian ekosistem laut. Dengan pengetahuan yang dimiliki nelayan dari yang mereka lihat dan alami, maka mereka mampu memodifikasi teknologi jaring trawl menjadi jaring cantrang. Bagi nelayan, cantrang membawa dampak positif bagi perekonomian nelayan, jaring cantrang tidak mengenal musim tangkap dan sasaran tangkapnya hampir semua jenis ikan.

Dampak dari kebijakan pelarangan penggunaan jaring cantrang oleh pemerintah, sangat mempengaruhi kondisi ekonomi dan sosial nelayan. Dari aspek ekonomi pendapatan nelayan menurun dan selama kurang lebih enam bulan nelayan melakukan aksi mogok melaut. Nelayan masih belum siap untuk pindah alat tangkap, karena pengetahuan mereka terhadap alat tangkap diperoleh secara turun temurun. Dari aspek sosial, hubungan antar tengkulak, tengkulak dengan nelayan, maupun tengkulak dengan pabrik terganggu stabilitasnya.[]

\section{Daftar Pustaka}

Ahimsa-Putra, Heddy Shri. 2007. Paradigma, Epistemologi, dan Etnografi dalam Antropologi. Yogyakarta: UGM Press.

Brata, Nugroho Trisnu. 2008. PT. Freeport dan Tanah Adat Kamoro Kajian TeoriTeori Antropologi. Semarang: Unnes Press.

Ermawati N, Zuliyati. 2015. "Dampak Sosial dan Ekonomi atas Peraturan Menteri Kelautan dan Perikanan Nomor 2/PERMEN-KP/2015 (Studi Kasus Kecamatan Juwana Kabupaten Pati)". 
Prosiding Seminar Nasional Multi Disiplin Ilmu \& Call for Papers Unisbank (SENDI_U) Kajian Multi Disiplin Ilmu untuk Mewujudkan Poros Maritim dalam Pembangunan Ekonomi Berbasis Kesejahteraan Rakyat ISBN: 978-979-3649-81-8 Diunduh di http://www.unisbank.ac.id/ojs/index. php/sendi_u/article/viewFile/3287/

Ginkel, R. V. 2007. Coastal Cultures: An Antrhropology of Fishing and Whaling Traditions. Apeldoorn: Het Spinhuis Publisher.

Miles, M.B. dan A. Michael Huberman. (1992). Analisis Data Kualitatif. Jakarta: UI Press.

Ritzer, G. \& Douglas J. G. 2015. Teori Sosiologi Modern. Jakarta: Kencana.

Sujarweni, V. W. 2014. Metodologi Penelitian. Yogyakarta: Pustaka Baru Press.
Yapanani E, Solichin A, Bambang Argo W. 2013. "Kajian Hasil Tangkapan dan Tingkat Kesejahteraan Nelayan di Desa Aromarea Distrik Kosiwo, Kabupaten Sarui, Kepulauan Yapen, Papua". Journal of Management of Aquatic Resources 2 (3): 197-202. (http://ejournals1.undip.ac.id/index.php/maquares)

Radar Pekalongan. 2015. "Nelayan Batang Tolak Permen Kelautan dan Perikanan No. 2 Tahun 2015". (http://www. radarpekalonganonline.com/60013/n elayan-batang-tolakpermen-kelautandan-perikanan-no-2-tahun-2015/).

Diakses pada tanggal tanggal 24 Februari 2017 pukul 21.00 WIB.

Kompas. 19 Januari 2018. "Penggantian Cantrang Terus Didorong". Halaman 1. 


\section{Author Guidelines}

\section{A. Persyaratan Umum}

1. Naskah merupakan hasil penelitian sosial keagamaan dan modernitas yang sudah diformat sesuai pola penulisan artikel jurnal ilmiah.

2. Naskah diutamakan ditulis dalam Bahasa Inggris.

3. Naskah merupakan karya orisinil (bukan plagiasi) dan belum pernah dimuat di jurnal atau media cetak/online lainnya.

4. Naskah dikirim ke Redaksi JSW: Jurnal Sosiologi Walisongo melalui submission Open Journal Systems (OJS) pada http://journal.walisongo.ac.id/index.php/jsw

5. Naskah diketik menggunakan Microsoft Word format RTF, font Times New Roman, size 12 pt, 1,5 spasi, ukuran halaman A4, dengan panjang tulisan 20-25 halaman (sekitar 5.000 - 7.000 kata).

6. Untuk menperoleh keterangan lebih lanjut, silakan menghubungi redaksi melalui email: jurnal.sosiologi@walisongo.ac.idatau menghubungi kantor redaksi (024) 76435986.

\section{B. Persyaratan Khusus}

1. Naskah merupakan hasil penelitian dalam bidang sosial keagamaan dan modernitas.

2. Naskah tidak mencantumkan nama penulis, instansi, dan alamat email. Nama penulis, instansi, dan alamat email dicantumkan saat melakukan registrasi OJS dan pengisian metadata naskah.

3. Naskah memuat:

a. Judul, dengan ketentuan:

- Judul merupakan rumusan pokok bahasan yang singkat, padat, dan jelas.

- Dalam judul sudah tercantum variabel-variabel utama penelitian.

- Judul diketik dengan hurup kapital tebal (capital, bold).

b. Abstrak, dengan ketentuan:

- Abstrak ditulis dalam bahasa Inggris dan bahasa Indonesia. 
- Abstrak merupakan intisari dari pokok bahasan naskah.

- Abstrak ditulis dalam satu paragraf berjarak satu spasi, dengan panjang 100250 kata.

- Abstrak disajikan secara singkat dan jelas, dengan memuat empa. argumentasi logis, perlunya dilakukan penelitian untuk memecahkan masalah, pendekatan yang digunakan (metode), hasil yang dicapai, serta simpulan yang diperoleh (IMRAD: introduction, methods, results, analysis and discussions).

c. Kata Kunci (keywords) maksimal 5 (lima) kata.

d. Isi naskah, dengan sistematika sebagai berikut:

- Pendahuluan yang meliputi latar belakang masalah, perumusan masalah, tujuan dan manfaat penelitian, serta metodologi yang digunakan (IMRAD: introduction, methods, results, analysis and discussions).

- Review pustaka yang berisi kajian teoretik dan hasil penelitian terdahulu yang relevan.

- Hasil dan pembahasan.

- Simpulan dan rekomendasi.

- Daftar pustaka.

4. Rujukan menggunakan ASA (American Sociological Association).[] 


\section{ACKNOWLEDGEMENTS}

The members of the editorial team of JSW: Jurnal Sosiologi Walisongo extend the gratitude to all the reviewers who have contributed to the peer review process of the manuscripts in Vol 1, No 2 (2017). Professional support and assistance from all respected reviewers have made this journal qualified to be published:

1. Abu Rokhmad, Universitas Islam Negeri Walisongo, Semarang

2. Agus Nurhadi, Universitas Islam Negeri Walisongo, Semarang

3. Misbah Zulfa Elizabeth, Universitas Islam Negeri Walisongo, Semarang

4. Muhyar Fananai, Universitas Islam Negeri Walisongo, Semarang

5. Najahan Musyafak, Universitas Islam Negeri Walisongo, Semarang

6. Thohir Yuli Kusmanto, Universitas Islam Negeri Walisongo, Semarang

7. TriMarhaeni Pudji Astuti, Universitas Negeri Semarang 


\section{\begin{tabular}{l|l} 
JW & $\begin{array}{l}\text { JURNAL } \\
\text { SOSIOLOGI } \\
\text { WALISONGO }\end{array}$
\end{tabular}}

JSW: Jurnal Sosiologi Walisongo - ISSN 2503-3166 (print) ISSN 2503-3182 (online) is a critical, reflective, and transformative academic media that is published by Laboratorium Sosiologi, Fakultas IImu Sosial dan IImu Politik, Universitas Islam Negeri Walisongo Semarang, in the effort for developing the discipline of Sociology having the perspective of unity of sciences. Article is based on research in all division of sociology like sociology of religion, sociology of politic, sociology of law, sociology of development, urban/rural sociology, democracy, social ethic, anthropology, community development, social philosophy, gender, and social welfare. 